Arq. Bras. Med. Vet. Zootec., v.65, n.6, p.1759-1766, 2013

\title{
Effect of sorghum tannins in sheep fed with high-concentrate diets
}

\author{
[Efeito do tanino do sorgo em dietas de ovinos com alto concentrado] \\ S.L.S. Cabral Filho ${ }^{1}$, A.L. Abdalla ${ }^{2}$, I.C.S. Bueno ${ }^{3}$, S.P. Gobbo ${ }^{2}$, A.A.M. Oliveira ${ }^{4}$ \\ ${ }^{1}$ Faculdade de Agronomia e Medicina Veterinária - Universidade de Brasília - Brasília - DF \\ ${ }^{2}$ Centro de Energia Nuclear na Agricultura - Universidade de São Paulo - Piracicaba, SP \\ ${ }^{3}$ Faculdade de Zootecnia e Engenharia de Alimentos - Universidade de São Paulo, Pirassununga, SP \\ ${ }^{4}$ Centro de Ciências Agrárias - Universidade Estadual do Oeste do Paraná - Marechal Cândido Rondon, PR
}

\begin{abstract}
The aim of this study was to evaluate the nutritional value of three sorghum cultivars with different concentrations of condensed tannins in sheep diets. Six adult sheep ( $\mathrm{LW}=56 \mathrm{~kg}$ ) with rumen and duodenal fistulas were assigned to experimental groups using two 3x3 Latin Square designs. The diets were formulated using three sorghum cultivars: LTC (low-tannin cultivar), MTC (medium-tannin cultivar) and HTC (hightannin cultivar). Microbial nitrogen $(\mathrm{MN})$ concentration in the duodenum was measured using a ${ }^{15} \mathrm{~N}$ trace technique. LTC, MTC and HTC diets presented values of 788, 722 and 747 (SE=20.6) $\mathrm{g} \mathrm{kg}^{-1}$ for dry matter digestibility and 633,535 and $530(\mathrm{SE}=35.8) \mathrm{g} / \mathrm{kg}$ for crude protein digestibility. The LTC diet was significantly different from the other diets $(\mathrm{P}<0.05)$. The nitrogen balance was $145.5,94.8$ and $83.8 \mathrm{~g} \mathrm{~kg}^{-1}$ ( $\mathrm{SE}=13.0)$ for LTC, MTC and HTC, respectively, with LTC showing greater nitrogen retention $(\mathrm{P}<0.05)$. Values obtained for MN in the digesta were 301, 364 and 469 ( $\mathrm{SE}=30.6) \mathrm{g} \mathrm{kg}^{-1}$ for LTC, MTC and HTC, respectively, and there was no statistical difference $(\mathrm{P}>0.05)$ between the diets. The presence of condensed tannins in the sorghum interfered with the sheep's nitrogen retention; however, the microbial protein supply to the duodenum of the animals was not inhibited.
\end{abstract}

Keywords: feed evaluation; microbial protein; nitrogen balance; rumen

\section{RESUMO}

O objetivo do presente estudo foi avaliar o valor nutricional de três cultivares de sorgo com diferentes concentrações de tanino condensado em dietas de ovinos. Seis carneiros machos, adultos, castrados, canulados no rúmen e duodeno foram divididos em três grupos experimentais, em um delineamento em quadrado latino $3 \times 3$. Os tratamentos foram representados por três dietas experimentais contendo diferentes cultivares de grão de sorgo: LTC (cultivar com baixa concentração de tanino), MTC (cultivar com concentração média de tanino) e HTC (cultivar com concentração alta de tanino). As concentrações de nitrogênio de origem microbiana no duodeno $(M N)$ foram mensuradas pela técnica de marcador isótopo estável 15N. As dietas LTC, MTC e HTC apresentaram valores de 788, 722 e 747g.kg-1 (EP=20,6) para a digestibilidade aparente da matéria seca e 633, 535 e 530g.kg-1 (EP=35,8) para a digestibilidade aparente da proteína bruta. A dieta LTC apresentou diferença significativa quando comparada às demais dietas para as avaliações de digestibilidade $(P<0,05)$. Os valores encontrados para o balanço de nitrogênio foram de 145,5; 94,8 e 83,8g.kg-1 (EP=13,0) para LTC, MCT e LTC, respectivamente, sendo a dieta LTC a que apresentou maior retenção de nitrogênio $(P<0,05)$. Os valores obtidos para $M N$ na digesta foram de 301 , 364 e 469 para LTC, MTC e HTC, respectivamente, e não apresentaram diferenças estatísticas $(P>0,05)$. As diferentes concentrações de taninos condensados nos cultivares de sorgo resultaram em melhorias na digestibilidade e retenção de nitrogênio das dietas, entretanto o fluxo de proteína microbiana não foi inibido.

Palavras-chave: avaliação de alimentos, balanço de nitrogênio, proteína microbiana rúmen

Recebido em 11 de julho de 2012

Aceito em 25 de junho de 2013

E-mail: slcabral@unb.br 


\section{INTRODUCTION}

The sorghum (Sorghum bicolor) grain is an important energetic resource in feeding ruminants. Despite the ruminant advantage of having an efficient fibre utilisation basis, the inclusion of greater amounts of starch in the finished sheep diet implies a larger accumulation of fat in the carcass and, therefore, better meat quality.

High concentrations of grains in ruminants' diets may result in negative effects on microbial fermentation (Mould, 1988). The high availability of fermentable carbohydrates and rapid microbial growth result in low $\mathrm{pH}$ values in the rumen, which inhibit the growth of cellulolytic microorganisms.

Some sorghum cultivars contain high concentrations of tannins in the kernels. The presence of these molecules in animal diets is associated with certain negative effects, such as a decrease in dry matter (DM) intake, a decrease in protein digestibility, a greater loss of endogenous protein and the inhibition of microbial activity (Makkar et al., 1995; Ben Salem et al., 1997, Godoy et al., 2004). On the other hand, studies have shown the positive effects of condensed tannins, including higher absorption of amino acids in the intestine, decreased nitrogen loss through urine and decreased endoparasites (Aerts et al., 1999; Athanasiadou et al., 2001).

It is the purpose of the present paper to evaluate diets formulated with different sorghum cultivars containing different concentrations of tannins in sheep nutrition.

\section{MATERIALS AND METHODS}

This experiment was performed in the Laboratório de Nutrição Animal do Centro de Energia Nuclear na Agricultura (CENA) of the Universidade de São Paulo (USP). The experiment was conducted using two simultaneous Latin Square designs with three treatments and six animals (Mead et al., 1999).

The animals used were six adult castrated sheep, predominantly of the Santa Inês breed. The animals had duodenum and rumen fistulas and initiated the experiment with an average weight of $56 \mathrm{~kg}$.
Three experimental diets were formulated: a lowtannin diet (LTC, with Agromen 8050), a medium-tannin diet (MTC, with SEMEALI hybrid) and a high-tannin diet (HTC with BR700); each diet used one of three different sorghum cultivars with increasing levels of condensed tannins (Tab. 1). The experimental diets were formulated according to the nutritional requirements and recommendations of the National Research Council (1985) for sheep. The recommendation for adult sheep was followed (>50kg of live weight) using a 20:80 forage:concentrate ratio (\% DM).

Table 1. Composition of the experimental diets: LTC (Agromen 8050), MTC (Semeali commercial hybrid) and HTC (BR700) formulated with three sorghum cultivars with different concentrations of condensed tannins (CT)

\begin{tabular}{|c|c|c|c|}
\hline $\begin{array}{l}\text { Ingredients/ } \\
\text { Diets }\end{array}$ & $\begin{array}{c}\text { LTC } \\
\left(\mathrm{g} \mathrm{kg}^{-1} \mathrm{DM}\right)\end{array}$ & $\begin{array}{c}\text { MTC } \\
\left(\mathrm{g} \mathrm{kg}^{-1} \mathrm{DM}\right)\end{array}$ & $\begin{array}{c}\text { HTC } \\
\left(\mathrm{g} \mathrm{kg}^{-1} \mathrm{DM}\right)\end{array}$ \\
\hline Hay & 200 & 200 & 200 \\
\hline Sorghum & 730 & 690 & 700 \\
\hline $\begin{array}{l}\text { Soybean } \\
\text { meal }\end{array}$ & 50 & 90 & 80 \\
\hline $\begin{array}{l}\text { Mineral } \\
\text { mixture }\end{array}$ & 20 & 20 & 20 \\
\hline $\begin{array}{l}C P \\
(g / k g M S)\end{array}$ & 120 & 120 & 120 \\
\hline $\begin{array}{l}M E \\
(M c a / k g)^{*}\end{array}$ & 2.57 & 2.58 & 2.58 \\
\hline$C T(\%)$ & 0 & 1.30 & 1.70 \\
\hline
\end{tabular}

* estimated according to the NRC for sheep (1985)

The concentrations of condensed tannins in the kernels of the three cultivars chosen for the experimental diets were determined. The concentrations of condensed tannins (CT) found were $0,10.9$ and $20.4 \mathrm{~g} \mathrm{~kg}^{-1}$ of DM for the three cultivars, respectively. They were analysed according to the Butanol/ $\mathrm{HCl}$ method described by Porter et al. (1986).

Coast-cross hay (Cynodon dactylon) with $10 \%$ crude protein (PB) was used as roughage. A commercial mineral supplement containing macro- and microminerals recommended for sheep (ovinofós-Tortuga) was included in the $\operatorname{diet}(2 \%$ of the DM).

The experimental diets were offered in a restricted form, fixed at $3 \%$ of the live weight of each animal per day. Food was given twice per 
day, at 8:30 and 16:30; the refusals, when there were any, were collected and weighed.

For each period, the animals were kept in metabolism cages during 14 days, including eight days for diet adaptation and six for the collection of the refusals, total faeces, urine, ruminal liquid (RL) and duodenal content (DC). Rumen infusions were also made using a ${ }^{15} \mathrm{~N}$ labelled solution in order to study microbial synthesis. Samples of RL were also collected for analysis of the ammonia nitrogen $\left(\mathrm{N}-\mathrm{NH}_{3}\right)$ content and rumen $\mathrm{pH}$ monitoring.

The refusals were collected daily, weighed and taken to an oven $\left(55^{\circ} \mathrm{C}\right.$ for $\left.48 \mathrm{~h}\right)$. The material was dried and ground $(1 \mathrm{~mm})$, avoiding the separation of roughage and concentrate. The samples were then analysed for the concentrations of the following: DM, organic matter $(\mathrm{OM})$, nitrogen $(\mathrm{N})$, crude protein $(\mathrm{CP})$, neutral detergent fibre (NDF) and acid detergent fibre (ADF). The analyses of N, CP and ADF were performed as established by the A.O.A.C (Association..., 1990) and the NDF analysis was performed as established by Van Soest et al. (1991).

All the faeces were collected and weighed. Afterwards, $10 \%$ aliquots of the total weight were taken from each sample. They were then dried $\left(55^{\circ} \mathrm{C}\right.$ during $\left.48 \mathrm{~h}\right)$, ground $(1 \mathrm{~mm})$ and submitted to the same analysis as the refusals.

The total urine was collected in a container with $100 \mathrm{~mL}$ of $10 \%$ sulphuric acid $\left(\mathrm{H}_{2} \mathrm{SO}_{4}\right)$. The total volume was measured on a daily basis and diluted in water until a final volume of three litres was reached. An aliquot of $20 \mathrm{~mL}$ was collected and frozen for eventual nitrogen analysis.

For the study of microbial synthesis and of the flux of microorganisms between the rumen and the duodenum, ${ }^{15} \mathrm{~N}$ was used as a marker. A solution of radiolabeled ammonium sulphate $\left[\left({ }^{15} \mathrm{NH}_{4}\right)_{2} \mathrm{SO}_{4}\right]$ was prepared with a $90 \%$ enrichment. The solution was diluted in $60 \mathrm{~mL}$ of distilled water and injected into the rumen of the animals through a syringe.

Every two hours, $2 \mathrm{~mL}$ of the solution was injected, such that the whole content of the syringes was applied over a $24-\mathrm{h}$ period. The animals received the solution for $72 \mathrm{~h}$ until the radiolabeled nitrogen was incorporated by the rumen microorganisms (steady-state). Each animal received a dose of $1 \mathrm{mg}$ of ${ }^{15} \mathrm{~N} \mathrm{~kg}^{-1}$ of live weight per day during the three days of infusion, as established by McAllan et al. (1994).

The collection of the DC started $36 \mathrm{~h}$ after the first injection of the marked salt solution. A minimum of $200 \mathrm{~mL}$ of DC was collected at 0,4 , $8,12,16,20,24,28,32,36,40,44,48,52,56$, $60,64,68$ and $72 \mathrm{~h}$. At each time point, $20 \mathrm{~mL}$ of the total quantity collected was separated and frozen $\left(-20^{\circ} \mathrm{C}\right)$.

After the conclusion of the experiment, the samples for all time points were homogenised every 24h, yielding three samples (pooled) representing DC 24, 48 and $72 \mathrm{~h}$ after the administration of the marker.

All the DC samples were lyophilised, weighed and analysed by mass spectrometry (ANCA, Europa Scientific). The levels of $\mathrm{N}$ and $\delta^{15} \mathrm{~N}$ (enriched with ${ }^{15} \mathrm{~N}$ ) in the samples were then determined.

RL samples were also taken at the end of the $72 \mathrm{~h}$ in order to determine the $\delta^{15} \mathrm{~N}$ content of the rumen microorganisms. The microorganisms were isolated from the ruminal content by centrifuging twice. Approximately $100 \mathrm{~mL}$ of RL was collected from each animal and centrifuged at $500 x g$ for 10 minutes. From the first centrifugation, only the supernatant was collected in order to separate the coarse particles of the RL. The supernatant portion was then centrifuged at $2000 \times \mathrm{g}$ for 20 minutes. After the second centrifugation the supernatant was discarded, yielding a pellet composed of bacteria in the liquid phase (LAB). The pellets were then lyophilised, weighed and subjected to mass spectrometry analysis.

The enrichment of the rumen microorganisms with ${ }^{15} \mathrm{~N}$ was calculated based on the $\delta{ }^{15} \mathrm{~N}$ values obtained in the pellet after $72 \mathrm{~h}$ minus the value of the natural enrichment of the isotope $(0.3663 \%)$, as provided by the International Atomic Energy Agency (IAEA). The same method was used to calculate the DC enrichment.

The amount of microbial nitrogen (MN) contained by the DC was calculated as 
established in studies by Brandt et al. (1980), McAllan et al. (1994), and Pérez et al. (1997), based on the following equation:

$$
\mathrm{MN} \%=\frac{{ }^{15} \text { Ndigesta }}{{ }^{15} \text { Nbacteria }}
$$

To determine the $\mathrm{pH}$ and the concentration of nitrogen in ammonia form in the RL, samples of RL were collected using a probe inserted directly into the rumen of the animals. Approximately $60 \mathrm{~mL}$ of RL were collected with the probe. The collections were undertaken at $0,0.5,1,1.5,2,3$, $4,5,6,9.5,14$ and $22 \mathrm{~h}$ after the first meal.

The RL was immediately transferred to a beaker, after which the $\mathrm{pH}$ was measured and an aliquot of approximately $10 \mathrm{~mL}$ was collected in glass containers. A few drops of concentrated $\mathrm{H}_{2} \mathrm{SO}_{4}$ $(18 \mathrm{~N})$ were added to the containers in order to reduce the loss of nitrogen through volatilisation. The tubes were then shaken and frozen. The concentrations of $\mathrm{N}-\mathrm{NH}_{3}$ in the $\mathrm{RL}$ were determined using a micro-Kjeldahl apparatus, following the methodology described by Preston (1995).

The Latin Square was the statistical design used for the experiment, as follows: $Y_{i j k}=\mu+t_{i}+a_{j}+$ $p_{k}+e_{i j k}$, where $t_{i}$ is the effect of treatment $i$ (diets), $a_{j}$ is the effect of animal $\mathrm{j}, \mathrm{p}_{\mathrm{k}}$ is the effect of the period $\mathrm{k}$ and $\mathrm{e}_{\mathrm{ijk}}$ is the associated error.

The model was analysed using the SAS program, Statistical... (2000), which was also used for comparisons of averages using Tukey's test at a $5 \%$ probability.

\section{RESULTS}

Table 2 demonstrates the results of consumption and apparent digestibility of dry matter (DMD), crude protein (CPD) and neutral detergent fibre (NDFD) as well as the nitrogen balance (NB) and microbial nitrogen (MN).

No significant differences $(\mathrm{P}>0.05)$ in $\mathrm{DM}$ intake were found. The DMD was different between the cultivars with high and low concentrations of tannins ( $\mathrm{P}<0.05)$ : $788 \mathrm{~g} \mathrm{~kg}^{-1}$ was the highest value, obtained with the LTD diet. The CP digestibility was higher $(\mathrm{P}<0.05)$ for the LTC diet, and no significant differences were found between the MTC and HTC diets. For the NDFD, the highest values obtained were for LTC and HTC, with an average of $582 \mathrm{~g} \mathrm{~kg}^{-1}$ for the MTC diet, which was different only from the LTC diet $(\mathrm{P}<0.05)$.

Table 2. Voluntary intake, dry matter digestibility (DMD), crude protein digestibility (CPD), nitrogen balance (NB), and microbial nitrogen (MN) in non-wool sheep consuming diets (LTC, MTC, and HTC) containing three sorghum cultivars with different concentrations of condensed tannins

\begin{tabular}{lcccccc}
\hline Diets & $\begin{array}{c}\text { Consumption } \\
\left(\mathrm{g} \mathrm{day}^{-1}\right)\end{array}$ & $\begin{array}{c}\text { DMD } \\
\left(\mathrm{g} \mathrm{kg}^{-1}\right)\end{array}$ & $\begin{array}{c}\mathrm{CPD} \\
\left(\mathrm{g} \mathrm{kg}^{-1}\right)\end{array}$ & $\begin{array}{c}\text { NDFD } \\
\left(\mathrm{g} \mathrm{kg}^{-1}\right)\end{array}$ & $\begin{array}{c}\text { NB } \\
(\%)\end{array}$ & $\begin{array}{c}\mathrm{MN} \\
\left(\mathrm{g} \mathrm{kg}^{-1}\right)\end{array}$ \\
\hline LTC & 1449 & $788 \mathrm{a}$ & $633 \mathrm{a}$ & $692 \mathrm{a}$ & $14.55 \mathrm{a}$ & 301 \\
MTC & 1430 & $722 \mathrm{~b}$ & $535 \mathrm{~b}$ & $582 \mathrm{~b}$ & $9.48 \mathrm{~b}$ & 364 \\
$\mathrm{HTC}$ & 1445 & $747 \mathrm{~b}$ & $530 \mathrm{~b}$ & $641 \mathrm{ab}$ & $8.38 \mathrm{~b}$ & 469 \\
\hline $\mathrm{P}>\mathrm{F}^{1}$ & 0.9644 & 0.0325 & 0.0094 & 0.0041 & 0.0051 & 0.1011 \\
$\mathrm{CV}^{2}(\%)$ & 9.1 & 4.7 & 10.8 & 6.2 & 20.9 & 37.1 \\
\hline 1- $\mathrm{P}<$ F probability of significance & ${ }^{2-}$ Coefficient of variation
\end{tabular}

As for the NB, the LTC diet showed a larger $(\mathrm{P}<0.05)$ retention of nitrogen $(14 \%)$ when compared to the $9 \%$ and $8 \%$ values obtained for MTC and HTC, respectively.

The MN content was expressed based on the total value of $\mathrm{MN}$ obtained in the digesta $\left(\mathrm{g} \mathrm{kg}^{-1}\right)$; there were no significant differences between the treatments $(\mathrm{P}>0.05)$.
A decline in ruminal $\mathrm{pH}$ values was observed after meals in all three treatment groups. The lowest averages were obtained at $3 \mathrm{~h}$ and $14 \mathrm{~h}$ after the first meal.

The ruminal $\mathrm{pH}$ values remained between 6.0 and 5.6 throughout the day. No significant differences were observed between the treatment groups $(\mathrm{P}>0.05)$, with all three diets displaying similar $\mathrm{pH}$ curves (Figure 1). 
The ammonia nitrogen $\left(\mathrm{N}-\mathrm{NH}_{3}\right)$ values obtained in the RL remained between 40 and $80 \mathrm{mg} \mathrm{L}^{-1}$ for all the treatment groups during the first $24 \mathrm{~h}$. Significant differences were observed between the treatment groups just $9 \mathrm{~h}$ after the first meal
(Figure 2). The LTC diet showed a concentration of $48 \mathrm{mg} \mathrm{L}^{-1}$, which was lower than the concentrations obtained for MTC and HTC (76 and $67 \mathrm{mg} \mathrm{L}^{-1}$, respectively).

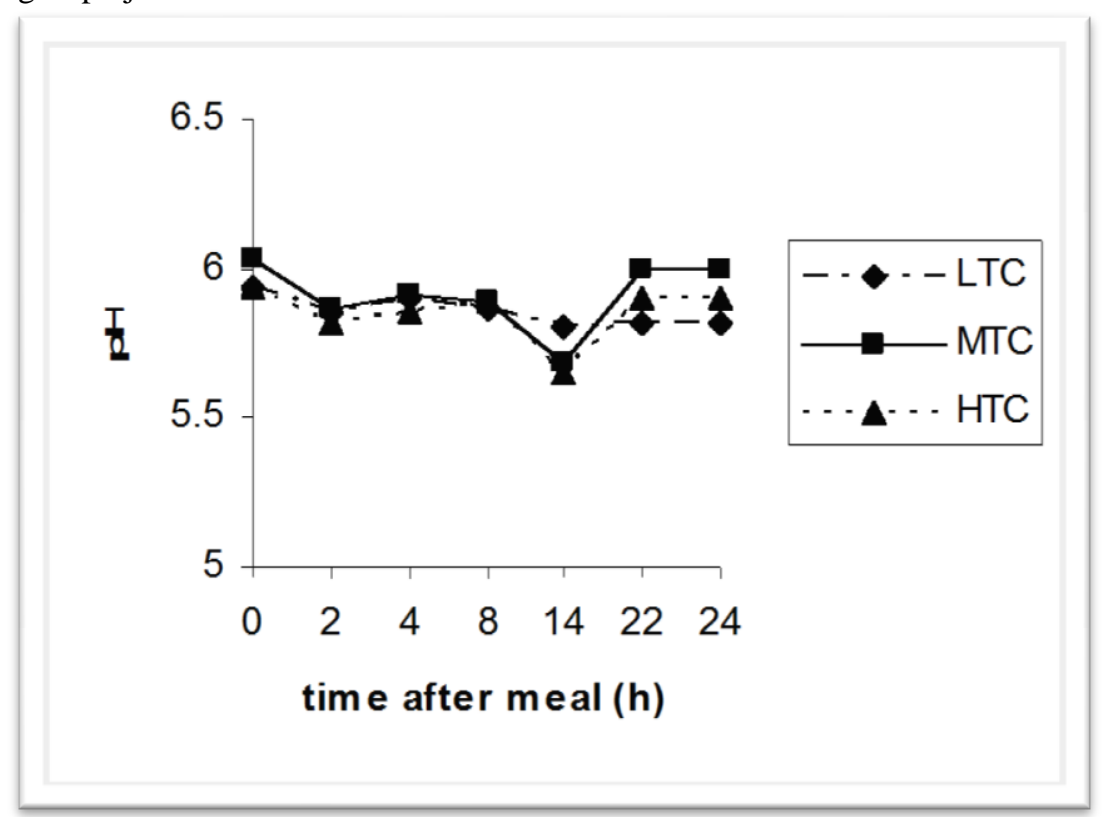

Figure 1. Ruminal $\mathrm{pH}$ variations in sheep fed with three different sorghum cultivars with different condensed tannin concentrations (LTC, MTC and HTC).

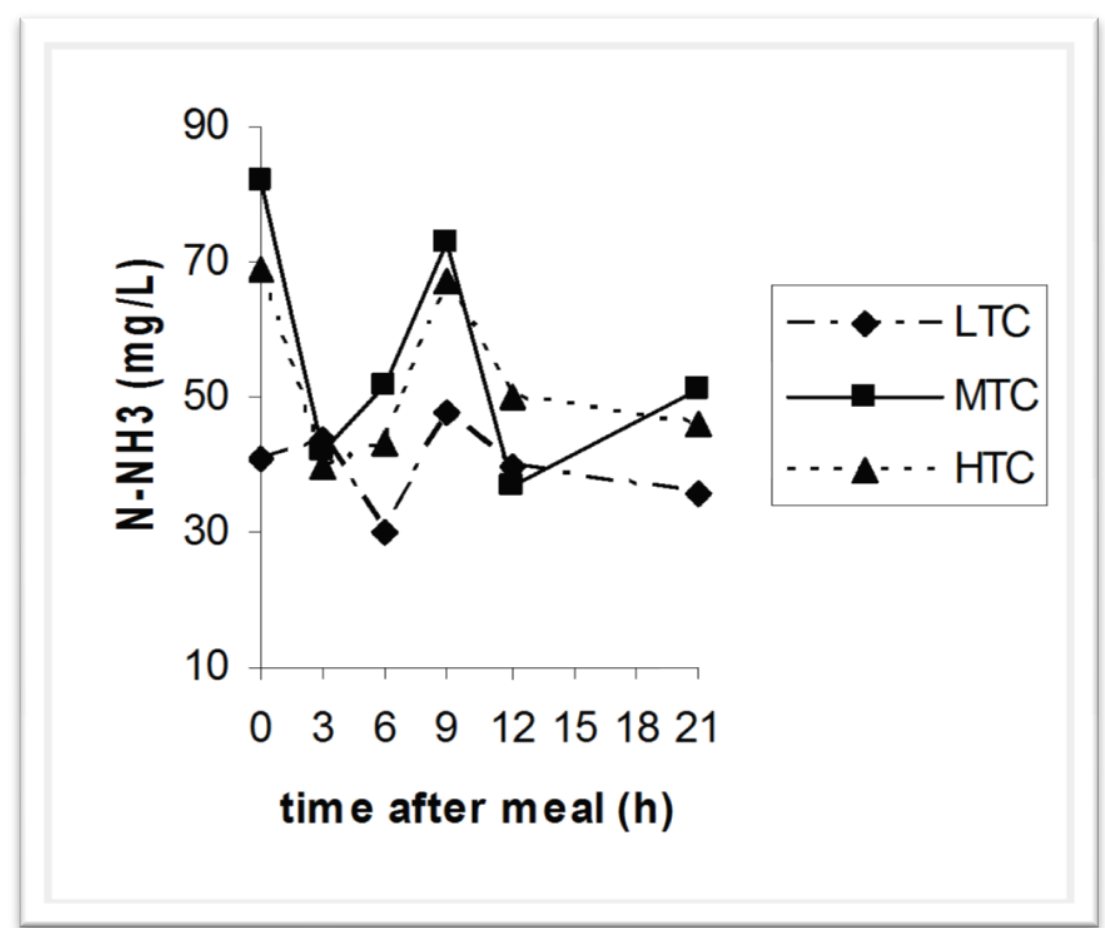

Figure 2. Variations in the ruminal $\mathrm{N}-\mathrm{NH}_{3}$ of ovines fed with three sorghum cultivars with different condensed tannin concentrations (LTC, MTC and HTC) 


\section{DISCUSSION}

There was no difference in the consumption of DM between the different diets, indicating that the cultivars with higher tannin concentrations did not present an astringent effect. A decrease in the palatability of rations due to the astringent effect of tannins was described by Butler and Rogler (1985). Some authors, such as McNaughton (1987), have observed negative effects on the voluntary intake of ruminants with tannin concentrations of $5 \%$ in the diet.

In studies conducted in Brazil with arboreal species from the Northeast (Silva et al., 1998; Beelen et al., 2003; Godoy et al., 2004), a decrease was observed in the sheep's voluntary intake, showing that consumption may be related not only to tannin concentration but also to the adaptation of the animals and the rumen microorganisms to the inhibitory effects of these molecules.

The values obtained for the apparent DMD indicate an efficient utilisation of these diets by the animals. Values between $72 \%$ and $77 \%$ for the organic matter digestibility (OMD) were found by Sherrod and Furr (1970) in sheep receiving $81 \%$ sorghum from different cultivars in their diets. Defoor et al. (2001), when comparing different plantation densities and processing methods for sorghum, obtained a value of $74 \%$ for the DMD in sheep fed with $60 \%$ grain.

The LTC diet presented the best DMD, indicating a possible effect of CT in the MTC and HTC diets. Such effects are associated with a larger loss of DM in the faeces due to its unavailability for fermentation and digestion. A decrease in DMD was described in in situ and in vitro experiments that used cultivars with highand low-tannin concentration grains (Campos et al. 2002; Cabral et al., 2003; Souza et al. 2003).

The CP digestibility also showed differences between the diets, with LTC showing a higher digestibility than MTC and HTC. The decrease in CPD is characteristic of the effect of CT in animal digestion. These molecules have a high affinity with proteins, causing the formation of bonds that can make this nutrient unavailable for absorption. Butler (1989) associated the reduction in protein digestibility by tannins with the reduction of enzymatic activity associated with protein digestion. Possible connections between the tannins and such enzymes would thus be responsible for such inactivity. Komolong et al. (2001) worked with increasing levels of quebracho extract (73\% CT in the DM) in sheep diets and noticed a $10 \%$ reduction in the nitrogen apparent digestibility $\left(\mathrm{R}^{2}=0.97\right)$ associated with an increase of $\mathrm{N}$ in the faeces $\left(\mathrm{R}^{2}=0.98\right)$.

The decrease in fibre digestibility was also described as an anti-nutritional effect of the CT (Reed, 2001). The present study found a significant decrease in NDFD for the MTC diet. Although this diet had $1.3 \%$ CT in the DM, no decrease in NDFD was observed for the HTC $\operatorname{diet}(1.7 \% \mathrm{CT}$ in $\mathrm{DM})$.

The nitrogen balance indicated a larger difference between the diets with and without tannins. Nitrogen retention was greater for the LTC diet (14.5\%), providing evidence of greater nitrogen use by the animals.

Some studies that evaluated nitrogen balance and retention in sheep fed with forage containing different CT concentrations noticed a greater nitrogen loss through the faeces and a decrease of such losses through urine (Ramirez et al., 1998; Ngwa, 2002). Such results indicate greater nitrogen retention for diets with moderate levels of CT (1-3\% of DM).

The nitrogen balance and digestibility results indicate a greater nitrogen loss by the animals that received $\mathrm{CT}$ in their diet, the microbial nitrogen (MN) levels in the DC did not show significant differences between the treatments ( $\mathrm{P}>0.05)$, indicating that the CT did not decrease the microbial activity of the rumen.

Experiments such as the one undertaken by Pérez et al. (1997) have yielded values of 11.9 and 11.5g MN per day for the $\mathrm{LAB}$ and the $\mathrm{SAB}$ measured using ${ }^{15} \mathrm{~N}$ in sheep receiving soybean meal diets with a high concentrate proportion.

Other studies that determined the $\mathrm{MN}$ concentrations in sheep fed with $80 \%$ concentrate in a restricted form and ad libitum obtained values of 14.5 and $17.4 \mathrm{~g}$ MN per day, respectively (Carro et al., 2000; Valdés et al., 2000). 
The low values of the rumen $\mathrm{pH}$ reflected the increase of lactic acid concentrations due to elevated proportions of concentrate in the diet. Decreases in the sheep's ruminal $\mathrm{pH}$ when they were fed diets with elevated proportions of concentrate have been described by Carro et al. (2000). The authors evaluated diets with different proportions of concentrate (80:20, 60:40, 40:60 and 20:80). The rumen $\mathrm{pH}$ values decreased linearly as concentrate levels increased $(6.45 ; 6.40 ; 6.20$ and 5.96; respectively).

The elevated proportions of concentrate and the low $\mathrm{pH}$ values may have been responsible for the low $\mathrm{N}-\mathrm{NH}_{3}$ concentrations found in the RL. Changes in the ruminal microbial population due to the extended digestion of starches may result in decreased protein digestion. Studies by Sultan and Loerch (1992) showed maximum values of 80 and $200 \mathrm{mg} \mathrm{L}^{-1}$ for sheep fed with 9.5 and $20 \%$ of $\mathrm{CP}$, respectively, whereas the highest values found by Valadares et al. (1997) in bovines were 90 and $200 \mathrm{mg} \mathrm{L}^{-1}$ for diets containing $7 \%$ and $14.5 \%$ of $\mathrm{CP}$, respectively.

\section{CONCLUSIONS}

The diets formulated from sorghum cultivars with higher concentrations of condensed tannins resulted in lower nitrogen use by the sheep. However, no decrease in the microbial nitrogen supply for intestinal absorption was identified. The study did not identify any anti-microbial action of the sorghum condensed tannins, but the hybrids that presented high levels of CT contributed to an important reduction in nitrogen retention.

\section{REFERENCES}

AERTS, R.J.; BARRY, T.N.; McNABB, W.C. Polyphenols and agriculture: beneficial effects of proanthocyanidins in forages. Agricult. Ecosyst. and Environment, v.75, p.1-12, 1999.

ASSOCIATION of Official Analytical Chemistry. Official methods of analysis, 15.ed. AOAC. Washington; 1990. 1141p.

ATHANASIADOU, S.; KYRIAZAKIS, I.; JAKSON, S.; COOP, R.L. Direct anthelmintic of condensed tannins towards different gastrointestinal nematodes of sheep: in vitro and in vivo studies. Vet. Parasitol., v.99, p.205-219, 2001.
BEELEN, P.M.G.; BERCHIELLI, T.T.; OLIVEIRA, S.G. et al. Influência dos taninos condensados sobre a degradabilidade ruminal da Jurema Preta (Mimosa hostilis), Sabiá (Mimosa caesalpinifolia) e Mororó (Bauhinia cheilantha). In: REUNIÃO ANUAL DA SOCIEDADE BRASILEIRA DE ZOOTECNIA, 40., Santa Maria, 2003. Anais... Santa Maria: SBZ, 2003. (Compact disc)

BEN SALEM, H.; NEFZAOUI, A.; BEN SALEM, L.; TISSERAND, J.L. Effects of Acacia cyanophylla Lindl. foliage supply on intake and digestion by sheep fed lucerne hay-based diets. Anim. Feed Sci. and Technol., v.68, p.101-113, 1997.

BRANDT, M., ROHR, K., LEBZIEN, P. Determination of microbial protein synthesized in the rumen by means of $15 \mathrm{~N}$. In: OSLAGE, H.J., ROHR, K. (Eds.). Protein Metabolism and Nutrition. EAAP Publication No. 23: Broderick, G.A., Merc, 1980. p.496-503.

BUTLER, L.G. Effects of condensed tannins on animal nutrition, In: HEMINGWAY, R.W.; KERCHESY, J.J. (Eds.). Chemistry and significance of condensed tannins. New York: Plenum Press, 1989. p.391-402.

BUTLER, L.G.; ROGLER, J. Enhancement of high tannins sorghum utilization: characterization, metabolism and detoxification of sorghum tannins and other polyphenols. In: WINN, J.F. (Ed.). Intsormil fighting hunger with research. Lincoln: University of Nebraska, 1985. p.140-145.

CABRAL, L.S.; VALADARES FILHO, S.C.; DETMANN, E. et al. Composição quimicobromatológica, produção de gás, digestibilidade in vitro da matéria seca e NDT estimado da silagem de sorgo com diferentes proporções de panículas. Rev. Bras. Zootec., v.32, p.1250-1258, 2003.

CAMPOS, F.P.; LANNA, D.P.D.; BOSE, M.L.V. et $a l$. Degradabilidade do capim-elefante em diferentes estágios de maturidade avaliada pelo método in vitro/gás. Scient. Agricola. v.59, p.217-225, 2002.

CARRO, M.D.; VALDÉS, C.; RANILLA, M.J.; GONZÁLVES, J.S. Effects of forage to concentrate ration in the diet on ruminal fermentation and digesta flow kinetics in sheep offered food at a fixed and restricted level of intake. Anim. Sci., v.70, p.127-134, 2000.

DEFOOR, P.J.; COLE, N.A.; GALYEAN, M.L. et al. Effects of grain sorghum planting and processing method on nutrient digestibility and retention by ruminants. J. Anim. Sci., v.79, p.19-25, 2001 
GODOY, P.B.; BUENO, I.C.S.; NOZELLA, E.F. et al. Intake and digestibility of tanniniferous browse species fed to sheep in three different levels of protein supply. (Compact disc) In: ANNUAL MEETING OF THE BRITISH SOCIETY OF ANIMAL SCIENCE. 2004. York. Proceedings... Penicuik: BSAS, 2004.

KOMOLONG, M.K.; BARBER, D.G.; McNEILL, D.M. Post-ruminal protein supply and $\mathrm{N}$ retention of weaner sheep fed on a basal diet of lucerne hay (Medicago sativa) with increasing levels quebracho tannins. Anim. Feed Sci. Technol., v.92, p.59-72, 2001

MAKKAR, H.P.S.; BLUMMEL, M.; BECKER, K. Formation of complexes between polyvinyl pyrrolidones or polyethylene glycols and tannins, and their implication in gas production and true digestibility in vitro techniques. British J. Nutrition. v.73, p.897-913, 1995.

McALLAN, A.B.; SUTTON, J.D.; BEEVER, D.E.; NAPPER, D.J. Rumen fermentation characteristics and duodenal nutrient flow in lactating cows receiving two types of grass silage with two levels of concentrate. Anim. Feed Sci. Technol., v.46, p.277291, 1994.

McNAUGHTON, S.J. Adaptation of herbivores to seasons changes in nutrient supply. In: HACKER, J.B.; TERNOUTH, J.H. (Eds.), Nutrition of Herbivores. Melbourne: Academic Press, 1987. p.391408.

MEAD, R.; CURNOW, R.N.; HASTED, A.M. Statistical Methods in Agriculture and Experimental Biology. London: Chapman \& Hall, cap.5, 1993. p.5988.: Control of random variation by blocking.

MOULD, F.L. Associative effects of feeds In: ØRSKOV, E.R. (Ed.). Feed Science - World Animal Science. Amsterdam: Elsevier Science Publishing, 1998. p.279-292.

NATIONAL Research Council - NRC. Nutrient requirements of sheep. 6.ed. Washington: National Academic Press, 1985. 99p.

NGWA, A.T.; NSAHLAI, Y.; IJI, P.A. Effects of supplementing veld hay with a dry meal or silage from pods of Acasia sieberian with or without wheat bran on voluntary intake, digestibility, excretion of purines derivatives, nitrogen utilization, and weight gain in South African Merino sheep. Livestock Prod. Scie.. v.77, p.253-264, 2002.

PÉREZ， J.F.; BALCELLS， J.A.;; GUADA，J.A.; CASTRILLO, C. Rumen microbial production estimated either from urinary purine derivative excretion or from direct measurements of $15 \mathrm{~N}$ and purine bases as microbial markers: effect of protein source and rumen bacteria isolates. Anim. Sci., v.65, p.225-236, 1997.
PORTER, L.J.; HRSTICH, L.N.; CHAN, B.G. The conversion of proanthocyanidins and prodelphinidins to cyanidin and delphinidin. Phytochemistry, v.25, p.223-230, 1986.

PRESTON, T.R. Biological and chemical analytical methods. In: PRESTON, T.R. Tropical Animal Feeding: A Manual for Research Workers. Rome: FAO, 1995. p.191-264.

RAMIREZ, R.G.; LARA, J.A. Influence of native shrubs Acacia rigidula, Cercidium macrum and Acacia farnesiana on digestibility and nitrogen utilization by sheep. Small Ruminant Res., v.28, p.39-45, 1998.

REED, J.D. Effects of proanthocyanidins on digestion of fiber in forages. J. Range Managment, v.54, p.466473, 2001

SHERROD, L.B.; FURR, R.D. Sheep digestibility of rations containing sorghum grains produced with different nitrogen fertilization rates. J. Anim. Sci., v.30, p.1042-1043, 1970 .

SILVA, A.M.A.; PEREIRA FILHO, J.M.; SOUZA, I.S. et al. Aceitabilidade por ovinos a espécies lenhosas do semi-árido paraibano. In: REUNIÃO ANUAL DA SOCIEDADE BRASILEIRA DE ZOOTECNIA, 35., Botucatu, 1998. Anais... Botucatu: SBZ, 1998. p.230-232.

SOUZA, V.G.; PEREIRA, O.G.; MORAES, S.A. et al. Valor nutritivo da silagem de sorgo. Rev. Bras. Zootec., v.32, p.753-759, 2003.

STATISTICAL Analysis Sistem - SAS INSTITUTE. The SAS systems for windows. Release 8.01. Cary, 2000.

SULTAN, J.I.; LOERC, S.C. Effects of protein and energy supplementation of wheat straw-based diets on site of nutrient digestion and nitrogen metabolism of lambs. J. Anim. Sci., v.70, p.2228-2234, 1992.

VALADARES, R.F.D.; GONÇALVES, L.C.; SAMPAIO, I.B. et al. Níveis de proteína em dietas de bovinos. 3. pH, amônia e eficiência microbiana. Rev. Bras. Zootec., v.26, p.1264-1269, 1997.

VALDÉS, C.; CARRO, M.D.; RANILLA, M.J.; GONZÁLES, J.S. Effect of forage to concentrate ration in complete diets offered to sheep on voluntary intake and some digestive parameters. Anim. Sci., v.70, p.119-126, 2000.

VAN SOEST, P.J.; ROBERSON, J.B.; LEWIS, B.A. Method for dietary fiber, neutral detergent fiber, and non-starch polysaccharides in relation to animal nutrition. J. Dairy Sci., v.74, p.3583-3597, 1991. 